\title{
KRIISISSÄ HYVINVOINTIVALTION MERKITYS KOROSTUU
}

\section{Pääkirjoitus}

\section{0}

Maailmanlaajuisen epidemian aikaansaanut Koronavirus COVID-19 ravistelee ihmisten arkea ja turvallisuuden tunnetta monin eri tavoin. Pandemia suuren mittakaavan yhteiskunnallisena ongelmana edellyttää laajoja kansallisia ja kansainvälisiä toimenpiteitä. Nämä toimenpiteet taas edellyttävät vahvaa hallintoa, tietoon perustuvaa päätöksentekoa, nopeaa ja asiallista viestintää sekä tehokasta toimeenpanoa. Demokraattisesti johdettu hyvinvointivaltio voi ideaalitapauksessa täyttää nämä kriteerit. Tällöin toimitaan parhaan olemassa olevan tiedon varassa siten, että taudin leviämistä rajoitetaan, terveydenhuollon kapasiteetti kestää ja riskiryhmiä suojellaan sekä taloutta kannatellaan riittävästi. Kun pandemiaan vastaamisessa on ollut hankaluuksia, on hyvinvoinnin sekatalous, etenkin markkinoiden keskeinen rooli siinä, asetettu uudella tavalla pohdinnan kohteeksi. Markkinoiden valvonnan höllentämisen, kaupan ja teollisuuden vapauttamisen ja julkisten palveluiden yksityistämisen on nähty heikentävän valtion kykyä varautua kriiseihin.

Riskiryhmien suojelemisessa suomalaisen hyvinvointivaltion heikkoudet ovat piirtyneet esiin. Koska koronavirus on erityisen vaarallinen vanhoille ihmisille, on annettu jyrkkiä ohjeistuksia siitä, miten yli 70-vuotiaiden on oltava karanteeninomaisissa oloissa. Ohjeissa ei huomioida sitä, millainen ihmisen terveydentila on. Yli 70-vuotiaiden ryhmän sisällä voi olla jopa yli 30 vuoden ikäeroja,joten ryhmä on hyvin heterogeeninen. Sosiaalinen eristäytyminen ja liikkumisen vähentyminen saattavat heikentää ihmisten toimintakykyä. On tärkeää pohtia päätöksenteon eettisiä ulottuvuuksia ja niiden taustalla vaikuttavia arvoja.

Yli seitsemänkymppisissä on yksi koronan suhteen erityisen haavoittuvassa asemassa oleva ryhmä: asumispalveluissa asuvat vanhukset. Hoiva tuo asukkaat ja työntekijät niin fyysisesti kuin psyykkisestikin lähelle toisiaan. Koska hoitajien on jatkettava elämäänsä: käytävä kaupassa ja huolehdittava läheisistään, altistuvat asumispalveluiden asukkaat väistämättä virukselle. Hoivakodeissa kuolemia on erityisen paljon eikä niitä alussa huomioitu koronaan kuolleiden määrissä. Yksittäisissä hoivakodeissa on saattanut jopa lähes puolet asukkaista kuolla koronavirukseen. Kotihoidon tilanteesta ei edes saada tietoa, vaikka kotona asuu paljon apua tarvitsevia vanhuksia. Asumispalveluiden korkeiden lukujen syiksi on ehdotettu ainakin epäselviä toimintaohjeita, liian vähäistä suojavarusteiden ja henkilöstön määrää, kiertäviä sijaisia ja sitä, että vanhusten hoivapalveluiden kustannuksia on jo pitkään yritetty rajoittaa ja jopa leikata. 
Huolta on kannettu myös muiden haavoittuvassa asemassa olevien ihmisten tilanteista, ja sosiaalisten ongelmien on ennakoitu pahenevan. Asunnottomien tilanne on vaikea, kun virusta ei voi pakoilla kotona. Lisäksi monet julkiset tilat, joissa on aiemmin voinut viettää aikaa lämpimässä, ovat suljettuna.

Pandemia tuottaa monia säröjä arjen rytmiikkaan. Kouluissa ja monissa työpaikoissa on siirrytty etätyöskentelyyn, joka kerää perheet koteihin aiempaa tiiviimpään vuorovaikutukseen. Perheenjäsenet ovat kotonaan totuttujen rooliensa lisäksi koululaisina, opiskelijoina, opettajina ja työntekijöinä. Perheen ulkopuolisten ihmisten kohtaamiselle on asetettu rajoitteita. Sosiaaliselle kanssakäymiselle on tullut uudenlaisia haasteita ja monille lapsille ja aikuisille koti on vaarallinen paikka.

Virus on tuonut esiin luokkajakoja. Etätyö on useammin mahdollista korkeammin koulutetuille. Yhteistoimintaneuvottelut ja lomautukset ovat koskettaneet yli 400000 työntekijää. Työttömyys lisää pienituloisuutta ja köyhyyttä ja nämä taas altistavat velkaantumiselle ja muille riskeille.

Sosiaalisten riskien ja ongelmien lisääntymistä voidaan jarruttaa ja niitä voidaan ratkaista hyvinvointivaltion avulla. Toimivien ratkaisujen löytämiseksi ja arvioimiseksi tarvitaan tieteellistä tutkimusta muun muassa koronan lyhyt- ja pitkäaikaisista vaikutuksista ihmisten hyvinvointiin, sosiaaliseen eriarvoisuuteen, toimeentuloon ja kouluttautumiseen. Onneksi Januksen vuoden 2020 toinen numero tarjoaa jälleen luettavaksi tärkeitä tutkimuksia, joista monilla on yhteys pandemian aikaiseen ja sen jälkeiseen hyvinvointivaltioon. Tuija Seppälä, Henrietta Grönlund ja Teemu Kemppainen kartoittavat tutkimuksessaan Helsingissä toimivat kohtaamispaikat ja tarkastelevat niiden sijaintia ja saatavuutta kaupunginosatasolla sosioekonomisen huono-osaisuuden näkökulmasta. Maria Tapola-Haapala ja Eveliina Heino tarkastelevat sosiaalityön opettajille suunnatun kyselyn avulla näkemyksiä kaunokirjallisuuden hyödyntämisestä sosiaalityön opetuksessa. Johanna Järvinen-Tassopoulos ja Minna Kesänen tutkivat sosiaalialan työntekijöiden asiantuntijuutta rahapeliongelmista kärsivien asiakkaiden ongelmien tunnistamisessa, heidän auttamisessaan ja ohjaamisessaan oikeanlaisten palvelujen äärelle. Joakim Zitting, Laura Hietapakka, Sanna Laulainen, Vuokko Niiranen ja Timo Sinervo analysoivat haastatteluiden avulla henkilöstön luottamusta organisaatioon ja johtajiin sosiaali- ja terveyspalvelujen organisaatiomuutoksessa. Tämä artikkeli sekä perustoimeentulotuen Kela-siirtoa käsittelevät puheenvuorot osoittavat miten asiantuntijoiden kuuleminen ja tutkittu tieto ovat äärimmäisen tärkeitä, kun hyvinvointivaltiota uudistetaan.

Kiinnostavia lukuhetkiä ja pidetään huolta myös hyvinvointivaltiosta!

Minna Zechner ja Marjo Romakkaniemi 